\title{
Islet transplantation in IDDM patients
}

\author{
A .Secchi ${ }^{1}$, C.Socci ${ }^{2}$, P.M affi ${ }^{1}$, M .V.Taglietti ${ }^{1}$, L.Falqui ${ }^{1}$, F. B ertuzzi ${ }^{1}$, P. D e N ittis ${ }^{2}$, L.Piemonti ${ }^{2}$, L. Scopsi ${ }^{3}$, \\ V. D i C arloㄹ, G . Pozza ${ }^{1}$ \\ ${ }^{1} \mathrm{D}$ epartment of I nternal M edicine, San R affaele Scientific I nstitute, U niversity of M ilan, M ilan, I taly \\ ${ }^{2} \mathrm{D}$ epartment of $\mathrm{G}$ eneral Surgery, San R affaele Scientific Institute, U niversity of M ilan, M ilan, I taly \\ ${ }^{3} \mathrm{D}$ epartment of Pathology, I stituto $\mathrm{N}$ azionale dei Tumori, M ilan, I taly
}

Summary This single-centre study investigated parameters that positively correlated with the success rate after islet allotransplantation in insulin-dependent diabetic (IDDM ) patients. Twenty-one intrahepatic, fresh islet transplantations were performed in 20 IDDM patients (one patient had two transplants), after or simultaneous with kidney transplantation. The correlation between number and purity of transplanted islets and final outcome was investigated. One patient died of a cardiac arrest several hours after islet transplantation; this patient was not included in the follow-up analysis. Three patients $(15 \%)$ experienced acute, irreversible, early failure of islet function, which was considered as a 'presumed rejection'. Nine patients ( $45 \%$ ) achieved either complete insulin-independence (seven cases) or a reduction ( $>50 \%$ ) of exogenous insulin requirement (two cases), with sustained serum C-peptide secretion $(0.89 \pm 0.04 \mathrm{nmol} / \mathrm{l}$; duration: $21 \pm 7$ months, range 2-58 months). Liver biopsy, per- formed 3 years after transplantation in one successful case, showed normal islets within the hepatic parenchyma. Eight cases (40\%) did not show any metabolic effect of islet transplantation, with low serum C-peptide levels ('presumed function exhaustion'). $M$ etabolic investigations performed in successful cases showed an early phase of insulin release after arginine, mild and reversible postprandial hyperglycaemia and normal $\mathrm{HbA}_{1 c}$ levels. Success of islet transplantation positively correlates with the number $(p<0.05)$ of the transplanted islets. I slet transplantation is a safe procedure, with $45 \%$ success rate, in terms of insulin-independence or relevant reduction of exogenous insulin requirement, although success can be transient. [D iabetologia (1997) 40: 225-231]

Keywords I slet transplantation, IDD M, immunosuppression, islet isolation.
Several reports have already shown that intrahepatic transplantation of purified islets can replace the pancreatic endocrine function in diabetic patients

R eceived: 20 J une 1996 and in final revised form: 280 ctober 1996

Corresponding author: A . Secchi, MD, D epartment of Internal M edicine, San Raffaele Scientific Institute, Via O Igettina 60, I-20132 M ilano, I taly

A bbreviations: ID DM, Insulin-dependent diabetes mellitus; SIK, simultaneous islet and kidney graft; I A K, islet after kidney transplantation; $\mathrm{A} \cup \mathrm{C}$, area under the curve; CV, coefficient of variation. without major side effects for either the patients or their liver function [1-5]. D espite these encouraging results, the data of the International I slet Transplant R egistry [6] are not as encouraging: in the 19891994 period only 28 out of 180 patients (16\%) maintained insulin independence for more than one week.

This paper reports the experience at one institute (San R affaele Scientific Institute, U niversity of $\mathrm{M} \mathrm{i-}$ Ian) with 21 cases of islet/kidney transplantations in insulin-dependent diabetic (IDDM) patients. The roles of islet mass and quality, immunosuppressive therapy and post-implantation management on the final outcome of fresh islet transplantation in IDDM patients are considered. 


\section{Subjects, materials and methods}

I solation and purification process. I slets from human pancreata (cadaver donors) were separated and purified using an automated procedure [7], modified as previously reported [8]. Cryopreservation of the purified islets was obtained following the method reported by Warnock et al. [9].

Q uantitative and qualitative assessment. I slet number, islet volume and insulin content were measured in 100- $\mu$ l aliquots removed from the preparation. The actual islet number was converted into $150-\mu \mathrm{m}$ diameter equivalents (equivalent number) and counted by the same person (C.S.). Purification of the islet preparations was assessed at optical microscope examination. Samples of materials used for pancreas preservation and islet isolation were cultured to verify the sterility of the transplanted islet preparations.

I slet transplantation. In all cases islets were injected into the liver. In the first seven patients the islets were injected into a branch of a mesenteric vein reached through a small midline laparotomy, under general anaesthesia. Patients 8-21 received the islets injected directly into the portal vein, using a percutaneous transhepatic approach, under local anaesthesia, in the radiology suite. Cephotaxime $(1 \mathrm{~g})$ was injected intravenously at $-1,7$ and $15 \mathrm{~h}$ after transplantation. Portal pressure was continuously monitored during the transplantation procedure.

Patients. Twenty C-peptide negative ID D M patients ( 12 males, 8 females) received 21 fresh islet transplantations (transplants 14 and 17 were performed in the same patient; the second transplant being performed 10 months after the first) from 1989 to 1995 at the San R affaele Scientific Institute. The mean age of the patients was $40 \pm 1$ years and the mean duration of diabetes $25 \pm 1$ years. E ight of these patients underwent a simultaneous islet and kidney graft (SIK). Thirteen of these patients, with established kidney grafts, underwent islet after kidney transplantation (IA K ). I nformed consent was obtained from all the patients.

I mmunosuppression. Patients undergoing SIK transplantation received antilymphocyte globulin (4250 lymphocytotoxic units $\cdot \mathrm{kg}^{-1} \cdot$ day $^{-1}$ antilymphocyte serum, Lymphoglobulin, M erieux, Lyon, France, or $125 \mathrm{mg} /$ day antithymocyte globulin, Thymoglobulin, Merieux) for 10 days; azathioprine $(2 \mathrm{mg} / \mathrm{kg}$ body weight, maximum dose $150 \mathrm{mg}$, depending on leukocyte count); steroids ( $500 \mathrm{mg}$ of prednisolone before surgery, followed by $0.25 \mathrm{mg} \cdot \mathrm{kg}^{-1} \cdot \mathrm{day}^{-1}$ body weight (b. w.), then tapered to $10 \mathrm{mg} / \mathrm{day}$ ); cyclosporin ( $7.5 \mathrm{mg} / \mathrm{kg}$ given orally when serum creatinine levels dropped below $265 \mu \mathrm{mol} / \mathrm{l}-7.6 \pm 2.3$ days after transplantation - and subsequently adjusted to cyclosporin blood levels).

Patients undergoing IAK transplantation continued with the immunosuppression established for the previously transplanted kidney (cyclosporin, azathioprine, steroids). For the first 10 days, therapy was given intravenously. Prednisolone (500 mg before islet infusion) and antilymphocyte globulins (Lymphoglobulin or Thymoglobulin, M erieux) were added, as in the SIK patients.

Post-transplant monitoring and management. Liver and kidney function were tested throughout the follow-up. For the first 10 days after transplant, blood glucose level was kept at 5.5 to $8.2 \mathrm{mmol} / \mathrm{l}$ by continuous intravenous insulin administration and subsequently by intensified subcutaneous insulin therapy (three injections per day). I nsulin doses were progressively tapered according to blood glucose levels and interrupted when fasting and postprandial blood glucose levels were lower than 6.6 and $8.8 \mathrm{mmol} / \mathrm{l}$, respectively. Patients were considered insulin-independent when these blood glucose levels were maintained without exogenous insulin for at least 1 week.

A ssessment of islet function. To assess the function of transplanted islets the following tests were performed:

1. Fasting C-peptide (daily);

2. G lycated haemoglobin ( $\mathrm{HbA}_{1 c}$, monthly, normal values less than $6.5 \%$ );

3. A rginine infusion test: $30 \mathrm{~g}$ of $\mathrm{L}$-arginine chlorhydrate ( $\mathrm{D}$ amor SpA, N aples, Italy) was infused intravenously over a 30min period and blood samples for serum insulin were collected at $0,5,10,20,30,45,60$ and $90 \mathrm{~min}$. The 0-60 min area under the curve $(A \cup C)$ for insulin was calculated according to the trapezoidal method.

4. 24-h metabolic profile; blood samples for serum glucose, Cpeptide and insulin assays were collected every $2 \mathrm{~h}$ for $24 \mathrm{~h}$.

Serum insulin (IRI) and C-peptide (C-PEP) levels were measured by specific radioimmunoassay; that is, insulin with Insulin I 125 Ria K it (Incstar Corporation, Stillwater, M inn., U SA ) and C-peptide with C-peptide D ouble A ntibody kit (D iagnostic Products Corporation, L os A ngeles, Calif., U SA ). In our laboratory the intra-assay coefficients of variation (CVs) for the above measurements were $3 \%$ and $3 \%$, while inter-assay CV s were $5 \%$ and $5 \%$, respectively.

M orphological and immunocytochemical studies. M orphological and immunocytochemical study was performed on one patient (3). A liver biopsy specimen was fixed overnight at room temperature in neutral-buffered $10 \%$ formalin, routinely embedded in paraffin and stained with haematoxylin-eosin. Insulin secreting cells were identified with antibodies to insulin (porcine insulin as an immunogen, raised in mouse, against human insulin -10-).

\section{Statistical analysis}

Statistical analysis was based on the $M$ ann-W hitney $U$-test (islet equiv/kg, islet absolute (abs)/kg, A U C after arginine) and on Student's t-test (fasting C-peptide). D ata are expressed as mean \pm SE M.

\section{Results}

Twenty-one islet transplants in 20 ID D M patients, after or simultaneous with kidney transplantation, have been performed at our institute since 1989. Fasting serum $C$-peptide levels above $0.33 \mathrm{nmol} / \mathrm{l}$ were detected in all cases after islet transplantation. These patients received $8283 \pm 838$ islets $/ \mathrm{kg}$ body weight (bw) (9433 \pm 735 islet equivalent/kg bw) separated from $1.3 \pm 0.1$ human pancreata per patient (pancreas weight $104 \pm 9 \mathrm{~g}$ ). Three patients received a mixed preparation (fresh and cryopreserved islets), while the other patients received only fresh islets. $\mathrm{Pa}$ tient 12 died in the operating theatre at the end of kidney transplantation because of a cardiac arrest, the islets having been injected under local anaesthesia by percutaneous transhepatic puncture, $3 \mathrm{~h}$ before the beginning of the kidney transplantation. This patient was not included in the following analysis. 
Table 1. Parameters of fresh islet preparations transplanted into the eight ID D M patients defined as presumed function exhaustion

\begin{tabular}{|c|c|c|c|c|c|}
\hline \multicolumn{2}{|c|}{ Patients } & \multirow{2}{*}{$\frac{\text { Pancreas }}{\text { No. }}$} & \multicolumn{2}{|l|}{ Fresh islets } & \multirow{2}{*}{$\frac{\text { Volume }}{(\mathrm{ml})}$} \\
\hline No. & $\begin{array}{l}\text { Weight } \\
(\mathrm{kg})\end{array}$ & & $\begin{array}{l}\text { E quivalent } \\
\text { number } \\
\text { kg/bw }\end{array}$ & $\begin{array}{l}\text { Purity } \\
(\%)\end{array}$ & \\
\hline $\begin{array}{l}2 \text { I IA K } \\
5 \text { SIK } \\
6 \text { SIK } \\
14 \text { SIK } \\
15 \text { SIK } \\
19 \text { IA K } \\
22 \text { SIK } \\
23 \text { SIK }\end{array}$ & $\begin{array}{l}50 \\
52 \\
54 \\
65 \\
54 \\
77 \\
62 \\
58\end{array}$ & $\begin{array}{l}2 \\
1 \\
1 \\
2 \\
1 \\
2 \\
1 \\
1\end{array}$ & $\begin{array}{r}6760 \\
3461 \\
4601 \\
11707 \\
4981 \\
11321 \\
8193 \\
8879\end{array}$ & $\begin{array}{l}85 \\
40 \\
40 \\
40 \\
60 \\
80 \\
50 \\
50\end{array}$ & $\begin{array}{c}0.6 \\
1 \\
0.5 \\
10 \\
2 \\
3 \\
3 \\
5\end{array}$ \\
\hline $\begin{array}{l}\text { M ean } \\
\pm \text { SE M }\end{array}$ & & $1.4 \pm 0.2$ & $7487 \pm 1088$ & $56 \pm 6$ & $3 \pm 1$ \\
\hline
\end{tabular}

IA K , I slet after kidney transplantation; SI K, simultaneous islet and kidney transplantation

E ight patients (Table 1 ) showed serum C-peptide levels above $0.33 \mathrm{nmol} / \mathrm{l}(0.40 \pm 0.02 \mathrm{nmol} / \mathrm{l})$ for an average of $4.5 \pm 1.5$ months (range 0.5 - 11 months), but no metabolic effects were observed. Insulin requirement 1 month after transplantation was $149 \pm 37 \%$ of pre-transplant doses. A progressive reduction of serum $C$-peptide levels was shown. They received fresh islets ( $5738 \pm 818$ islet $/ \mathrm{kg}, 7487 \pm 1088$ islet equivalent/kg bw) separated from $1.4 \pm 0.2$ human pancreata per patient (pancreas weight $99 \pm 15 \mathrm{~g}$ ). Donor age was $36 \pm 4$ years and cold ischaemia time was $2.5 \pm 0.2 \mathrm{~h}$. I slet purification was $59 \pm 3 \%$. These patients were described as having 'presumed function exhaustion'.

Three patients (Table 2) showed sustained C-peptide levels after transplantation $(0.62 \pm 0.06 \mathrm{nmol} / \mathrm{l})$. A sharp reduction in C-peptide levels was observed as a consequence of presumed acute islet rejection at 1,2 and 4 weeks, respectively, after transplantation. Patient 1 was not prophylactically treated with antilymphocyte globulin, due to previous cytomegalovirus uveitis, while $A L G$ was suspended in patient 7 due to serum sickness. Patient 13 developed acute vascular kidney rejection, which was steroid resistant, concurrently with disappearance of C-peptide in the serum. They received $7681 \pm 2437 / \mathrm{kg}$ fresh islets (9096 \pm 2681 islet equivalent/kg bw), separated from $1.3 \pm 0.3$ pancreata per patient (pancreas weight: $103 \pm 26 \mathrm{~g}$ ). D onor age was $32 \pm 9$ years and cold ischaemia time was $3.5 \pm 0.3 \mathrm{~h}$. Islet purification was $60 \pm 10 \%$. Two patients received only fresh islets, while one patient received a mixed preparation (fresh and cryopreserved). These patients were described as having 'presumed rejection'.

Nine patients ( $45 \%$ of cases) showed a progressive reduction in exogenous insulin requirement (Table 3): insulin requirement 1 month after transplantation was $46+9 \%$ of pretransplant doses. Good metabolic control was maintained during the entire follow-up period, as shown by $\mathrm{HbA}_{1 c}$ levels (Table 4). These patients were described as being successful cases. They included patients who

Table 2. Parameters of islet preparations transplanted into the three ID D M patients defined as presumed rejection

\begin{tabular}{|c|c|c|c|c|c|c|c|}
\hline \multicolumn{2}{|l|}{ Patients } & \multirow{2}{*}{$\frac{\text { Pancreas }}{\text { No. }}$} & \multicolumn{2}{|l|}{ Fresh islets } & \multicolumn{2}{|c|}{ Cryo islets } & \multirow{2}{*}{$\frac{\text { Volume }}{(\mathrm{ml})}$} \\
\hline No. & Weight (kg) & & $\begin{array}{l}\text { Equivalent number } \\
\mathrm{kg} / \mathrm{bw}\end{array}$ & Purity (\%) & Pancreas & $\begin{array}{l}\text { A bsolute number } \\
(\times 1000)\end{array}$ & \\
\hline M ean \pm SE M & $67 \pm 12$ & $1.3 \pm 0.3$ & $9096 \pm 2681$ & $60 \pm 10$ & & & $2.4 \pm 0.9$ \\
\hline
\end{tabular}

I A K, I slet after kidney transplantation; SIK, simultaneous islet and kidney transplantation

Table 3. Parameters of islet preparations transplanted in the nine ID D M patients defined as successful

\begin{tabular}{|c|c|c|c|c|c|c|c|}
\hline \multicolumn{2}{|l|}{ Patients } & \multirow{2}{*}{$\frac{\text { Pancreas }}{\text { No. }}$} & \multicolumn{2}{|l|}{ Fresh islets } & \multicolumn{2}{|c|}{ Cryo islets } & \multirow{2}{*}{$\frac{\text { Volume }}{(\mathrm{ml})}$} \\
\hline No. & Weight $(\mathrm{kg})$ & & $\begin{array}{l}\text { Equivalent number } \\
\mathrm{kg} / \mathrm{bw}\end{array}$ & Purity (\%) & Pancreas & $\begin{array}{l}\text { A bsolute number } \\
(\times 1000)\end{array}$ & \\
\hline M ean \pm SE M & $53 \pm 2$ & $1.3 \pm 0.2$ & $11137 \pm 907$ & $70 \pm 7$ & & & $2.5 \pm 0.5$ \\
\hline
\end{tabular}

IA K, I slet after kidney transplantation; SIK, simultaneous islet and kidney transplantation 
Table 4. Fasting $\mathrm{C}$-peptide ( $\mathrm{nmol} / \mathrm{l})$ and glycated haemoglobin $\left(\mathrm{H} \mathrm{bA}_{1,} \%\right)$ in nine patients after successful islet transplant

\begin{tabular}{|c|c|c|c|c|c|c|c|c|c|c|c|c|c|c|c|c|}
\hline \multirow{3}{*}{$\begin{array}{l}\mathrm{Pa}- \\
\text { tients }\end{array}$} & \multirow{2}{*}{\multicolumn{2}{|c|}{$\begin{array}{l}\text { pre- } \\
\text { transplant }\end{array}$}} & \multicolumn{14}{|c|}{ M onth post-transplant } \\
\hline & & & \multicolumn{2}{|l|}{3} & \multicolumn{2}{|l|}{6} & \multicolumn{2}{|l|}{12} & \multicolumn{2}{|l|}{24} & \multicolumn{2}{|l|}{36} & \multicolumn{2}{|l|}{48} & \multicolumn{2}{|l|}{60} \\
\hline & $\begin{array}{l}\text { C-pep- } \\
\text { tide }\end{array}$ & $\mathrm{HbA}_{1 \mathrm{c}}$ & $\begin{array}{l}\text { C-pep- } \\
\text { tide }\end{array}$ & $\mathrm{HbA}_{1 \mathrm{c}}$ & $\begin{array}{l}\text { C-pep- } \\
\text { tide }\end{array}$ & $\mathrm{HbA}_{1 \mathrm{c}}$ & $\begin{array}{l}\text { C-pep- } \\
\text { tide }\end{array}$ & $\mathrm{HbA}_{1 \mathrm{c}}$ & $\begin{array}{l}\text { C-pep- } \\
\text { tide }\end{array}$ & $\mathrm{HbA}_{1 \mathrm{c}}$ & $\begin{array}{l}\text { C-pep- } \\
\text { tide }\end{array}$ & $\mathrm{HbA}_{1 \mathrm{c}}$ & $\begin{array}{l}\text { C-pep- } \\
\text { tide }\end{array}$ & $\mathrm{HbA}_{1 \mathrm{c}}$ & $\begin{array}{l}\text { C-pep- } \\
\text { tide }\end{array}$ & $\mathrm{HbA}_{1 \mathrm{c}}$ \\
\hline 3 & 0.05 & 7.3 & 0.99 & 7.1 & 1.49 & 6.9 & 1.09 & 7.6 & 0.63 & 7 & 1.5 & 7.3 & 0.4 & 6.5 & - & \\
\hline 4 & 0.05 & 7.6 & 0.60 & 5.5 & 0.73 & 4.8 & 0.33 & 6.6 & 0.46 & 6.6 & 0.3 & 8.7 & 0.36 & 5.8 & 0.51 & $7 \rightarrow$ \\
\hline 8 & 0.05 & 4.5 & 0.66 & 4.5 & 0.56 & 6 & 1.19 & 7.5 & 0.40 & 7.3 & & & & & & \\
\hline 10 & 0.04 & 10.4 & 1.89 & 6.2 & 1.59 & 7.1 & 0.69 & 5.8 & 0.83 & 5.2 & 0.99 & 6.3 & $\rightarrow$ & & & \\
\hline 18 & 0.02 & 4.8 & 1.09 & 5.9 & - & - & 0.79 & 8.7 & & & & & & & & \\
\hline 20 & 0.15 & 6.7 & 0.33 & 5.5 & 0.5 & 6 & & & & & & & & & & \\
\hline 21 & 0.01 & 8.5 & 1.03 & - & 0.01 & 5.6 & $\rightarrow$ & & & & & & & & & \\
\hline
\end{tabular}

A rrows indicate that function is still present
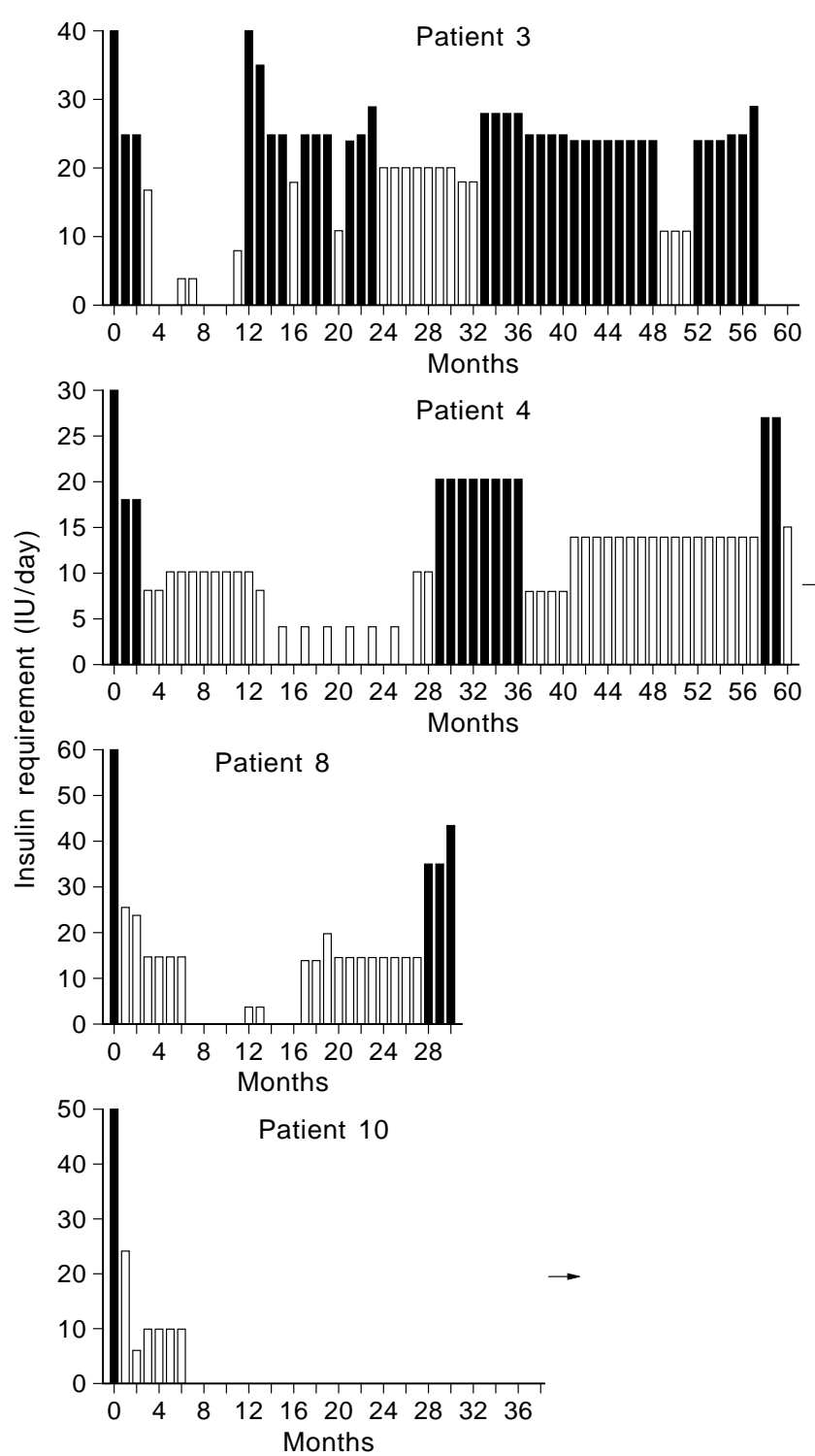

Fig. 1. Exogenous insulin requirement (IU/day) in four patients after successful islet transplantation. A reduction of exogenous insulin requirement to less than $50 \%$ of pretransplant values was arbitrarily considered successful: $\square$. Exogenous insulin requirement higher than $50 \%$ pre-transplantation values: $\mathbf{\square}$. A rrows indicate still functioning transplant achieved complete insulin independence and patients whose exogenous insulin doses were reduced to less than $50 \%$ of pretransplant doses. They received $10615 \pm 1284 / \mathrm{kg}$ fresh islets (11137 \pm 907 islet equivalent $/ \mathrm{kg} \mathrm{bw}$ ), separated from $1.3 \pm 0.2$ human pancreata per patient (pancreas weight $110 \pm 16 \mathrm{~g}$ ). D onor age was $34 \pm 4$ years and cold ischaemia time was $4.6 \pm 1.1 \mathrm{~h}$. Islet purification was $70 \pm 7 \%$. Five patients received only fresh islets, while two patients received a combination of fresh and cryopreserved islets. These patients showed high fasting serum Cpeptide levels (Table 4) that lasted $21 \pm 7$ months (range 2-58 months). Seven of these patients (nos. 3, $4,8,10,16,18$ and 21) achieved complete insulin-independence within 4, 15, 6, 6, 2, 1 and 2 months, respectively, which lasted for $7,11,10,40,1,1$, and 1 month, respectively. Insulin-independence was still ongoing in patient no. 10 after 48 months, while the other patients have resumed low doses of insulin. Individual insulin requirement is reported in Figures 1 and 2. M etabolic effects (exogenous insulin requirement $<50 \%$ of pretransplant doses) are still present after $60,48,18$ and 9 months, respectively, in patients nos. 4, 10, 17, 21.

The number of transplanted islets was statistically higher in successful cases than in patients with presumed function exhaustion (E quivalent number/kg: $11137 \pm 907$ vs $7487 \pm 1025, p=0.03$; absolute number/kg: $10615 \pm 1284$ vs $5738 \pm 771, p=0.009)$. The rate of islet purity was higher, although not statistically, in the former than in the latter group ( $70 \pm 7$ vs $56 \pm 6 \%$ ). Fasting serum C-peptide levels were higher in successful cases than in presumed function exhaustion cases $(0.89 \pm 0.04$ vs $0.40 \pm 0.02 \mathrm{nmol} / \mathrm{l}$, $p<0.0001)$. Patients experiencing islet rejection showed higher $\mathrm{C}$-peptide levels than patients with presumed function exhaustion $(0.62 \pm 0.06$ vs $0.40 \pm 0.02 \mathrm{nmol} / \mathrm{l}, \mathrm{p}<0.0001$ ). No statistical difference was observed, in terms of pretransplantation insulin requirement, between successful and presumed function exhaustion cases $(0.76 \pm 0.06$ vs $1.09 \pm$ $0.27 \mathrm{IU} / \mathrm{kg} \mathrm{bw}$, respectively). 

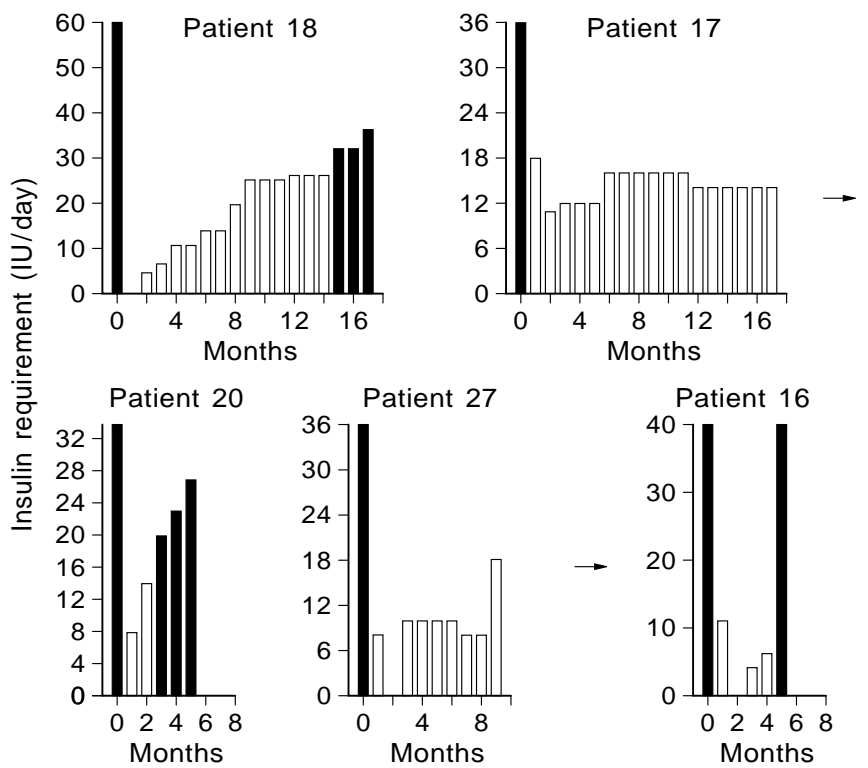

Fig. 2. Exogenous insulin requirement (IU/day) in five patients after successful islet transplantation. A reduction of exogenous insulin requirement to less than $50 \%$ of pre-transplant values was arbitrarily considered successful: $\square$. Exogenous insulin requirement higher than $50 \%$ pre-transplantation values: $\mathbf{a}$. A rrows indicate still functioning transplant

Morphological and immunocytochemical studies. Three years after islet transplantation (fasting serum C-peptide: $1.53 \mathrm{nmol} / \mathrm{l}$ ), a liver biopsy was performed in patient no. 3 during cholecystectomy for acute cholecystitis. As shown in Figure $3 a$ (staining with haematoxylin-eosin) the islets are situated in a portal space. They are well-preserved, with no signs of cellular infiltrates, while the hepatic parenchyma surrounding the islets appears totally normal. Immunocytochemical studies (Fig. 3b) showed a normal distribution of insulin-producing cells within the islets.

M etabolic effects of islet transplantation. 24-h metabolic profiles were not performed at the same time intervals, but when patients achieved insulin-independence (patients 3, 8, and 16 at 6 months: patient 4 at 12 months; patient 10 at 24 months). Fasting blood glucose level was $6.4 \pm 0.6 \mathrm{mmol} / \mathrm{l}$. M ild and reversible postprandial hyperglycaemia $(9.0 \pm 0.7 \mathrm{mmol} / \mathrm{l})$ was observed. A rginine test was performed between 1 and 3 months after transplantation in five patients of the successful group and in two patients of the presumed function exhaustion group. A U C for insulin (0-60 $\mathrm{min}$ ) was higher, although not statistically, in the former group $(10836 \pm 2058 \mathrm{pmol} / 60 \mathrm{~min})$ than in the latter group ( $5250 \pm 2532 \mathrm{pmol} / 60 \mathrm{~min})$. The same test, performed in three patients during insulin-independence, showed a prompt release of insulin, with a peak at $5 \mathrm{~min}(248 \pm 29 \mathrm{pmol} / \mathrm{l})$.

Side effects. O ne case of peritoneal bleeding was observed, which did not require surgery and recovered spontaneously. Medical complications included one case of serum sickness and one case of candidiasis. These complications were successfully treated with medical therapy. Patients 3 and 17 experienced an episode of rejection of the previously transplanted kidney, 3 weeks after islet transplantation in both cases. Serum creatinine rose to 390 and $170 \mu \mathrm{mol} / \mathrm{l}$, respectively (basal value: 80 and $123 \mu \mathrm{mol} / \mathrm{l}$, respectively). These episodes were successfully treated with steroid administration ( $500 \mathrm{mg}$ of prednisolone, 2 and 3 pulses, respectively).

\section{Discussion}

The aim of islet transplantation is to achieve insulinindependence and to maintain good metabolic control in IDDM patients with minor surgery. A fter the first successful case reported in 1989 [1] several clinical islet programs were developed, which are registered in the Islet Transplant R egistry, held by the $U$ niversity of $G$ iessen ( $G$ ermany). We have classified IDDM patients who achieved insulin-independence or good metabolic control with a relevant reduction (>50\%) of previous exogenous insulin requirement and elevated serum C-peptide levels, after islet/kidney transplantation, as successful cases. A reduction of exogenous insulin requirement to less than $50 \%$ of pretransplant doses can be considered the effect of endogenous insulin secretion and not the consequence of external influencing factors, mainly insulin-sensitivity, since all but one (15) of the patients did not receive high doses of insulin before transplantation, thus indicating that severe insulin resistance was not present. A ccording to this definition, islet transplantation was successful in $45 \%$ of our cases. Four $(20 \%)$ of our patients were insulin-independent at 1 year, compared with $11 \%$ reported by the R egistry [6]. $\mathrm{H}$ istological studies showed that 3 years after transplantation the islets were situated in the portal space: they were normal, with a normal distribution of insulin-producing cells, as was already reported in one case a few hours after transplantation [11].

The parameters which, according to our data, positively influence the success in islet transplantation are as follows. N umber of isl ets: A II successfully transplanted patients received a higher equivalent number of islets than presumed function exhaustion patients. The number of pancreata required to obtain islets for each transplant (1.3) is lower than that reported in the literature [6], thus indicating that the isolation procedure is adequate. If we consider 6200 islets $/ \mathrm{kg}$ bw (lowest number of islets transplanted in a successful case) as the cut-off point for the highest probability of successfully transplanted islets, we can see that, among the 12 patients receiving this amount of islets, $75 \%$ were successful. To date only preparations with at least 6200 islets/kg bw should be considered 


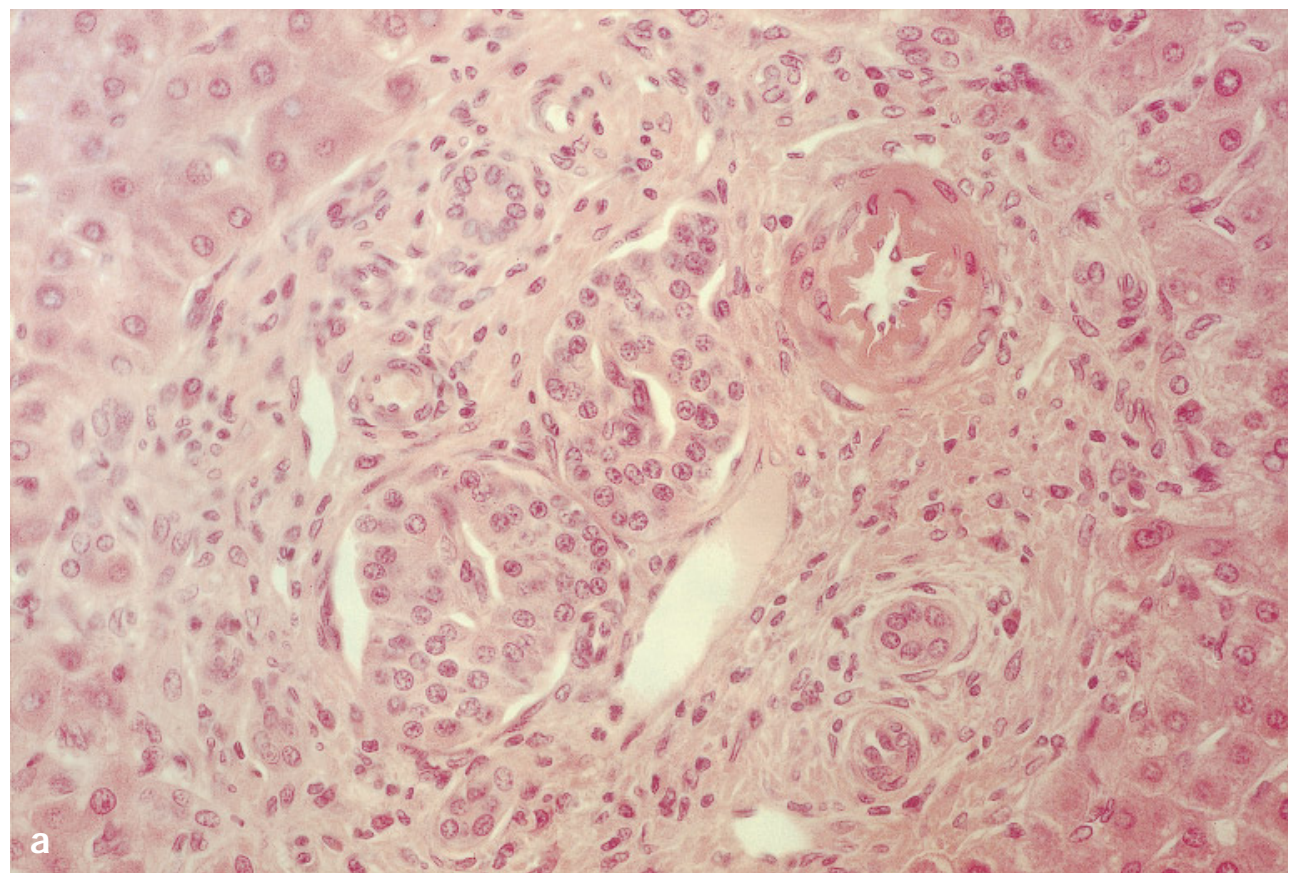

Fig. 3. (a, b) Liver biopsy performed in patient 3 , at 3 years after islet transplantation.

a $\mathrm{H}$ aematoxylin-eosin staining: islets are situated in a portal space. They are very well-preserved, with no sign of cellular infiltrate, while the hepatic parenchyma surrounding the islets appears totally normal. b Immunocytochemical studies performed with antibodies to insulin (porcine insulin as an immunogen, raised in mice, against human insulin -10-) showed a normal distribution of insulinproducing cells within the islets

b

for transplantation. These analyses were only performed on fresh islet preparations, since there is no evidence that cryopreserved islets can exert any metabolic effect in humans. Strict metabolic control: It has been reported by the International R egistry [6], that strict metabolic control can protect the islets, with positive effects on outcome. All our patients were treated intensively with insulin (i.v. or s. c.) in the post-surgical period, thus achieving good metabolic control. While it is not clear from our data whether good metabolic control in the early post-surgical period can protect the islets, the negative effects of so-called glucotoxicity on islet function have already been shown in vitro [12] and in vivo [13]. Furthermore, there is evidence that strict metabolic control at the onset of diabetes increases the incidence of the remission (honeymoon) phase [14]; this protective role may be active in the case of islet transplantation. A rginine A U C for insulin, which can be considered a parameter of islet function, indicating the effective engraftment of the islets, was higher in the successful cases than in presumed function exhaustion cases, although the small number of observations does not allow a statistical evaluation. From these data it seems that a better engraftment, as expected, is achieved in successful cases. Strict metabolic 
control could play a relevant role in promoting the engraftment of islets. L arger samples are required to understand the reasons for this behaviour. Immunosuppression. The protective role of severe immunosuppression seems to play a major role in explaining these results. Presumed rejection was observed in those patients who were not receiving antilymphocyte globulin or who experienced acute renal vascular rejection, resistent to steroids or OKT3 treatment, thus indicating a severe immune activation.

The metabolic behaviour of the transplanted islets is similar to segmental pancreas transplantation [15], in terms of insulin release after i. v. arginine [16]. The 24-h metabolic profile, studied when our patients were insulin-independent, shows a mild postprandial hyperglycaemia. D espite these abnormalities, good metabolic control (as shown by glycated haemoglobin levels) is achieved in successfully treated patients.

In conclusion this study confirms that strict metabolic control and severe immunosuppression have a protective effect on islets and improve the outcome of islet transplantation. It also shows that the number of islets transplanted positively correlates with successful grafts. This procedure is safe and offers a $45 \%$ success rate in terms of insulin-independence or relevant reduction of exogenous insulin requirement (under strict metabolic control), although in some cases these results are transient.

A cknowledgements. This work was partially supported by the I talian M inistry of $\mathrm{H}$ ealth (R icerca Finalizzata 1990), the $\mathrm{Na}$ tional R esearch Council (CNR, grant \#90.00034.PF 70), Telethon (grant \# C.11), R egione L ombardia (grant \# 879) and the Juvenile Diabetes Foundation (C.S.: International Post D octoral Fellowship, \#390196)

\section{References}

1. Warnock G L, Kneteman NM, R yan E A et al. (1989) Continued function of pancreatic islets after transplantation in type I diabetes. L ancet 334: 570-572

2. Scharp DW, L acy PE, Santiago J V et al. (1990) Insulin independence after islet transplantation into a type I diabetic patient. Diabetes 39: 515-518
3. Tzakis A G, R icordi C, A lejandro R et al. (1990) Pancreatic islet transplantation after upper abdominal and liver replacement. L ancet 336: 402-405

4. Socci C, Falqui L, D avalli A M et al. (1991) Fresh human islet transplantation to replace pancreatic endocrine function in type I diabetic patients. A cta D iabetol 28: 151-157

5. Gores PF, N ajarian J S, Stephanian E, L loveras JJ, K elley SL, Sutherland D E R (1993) Insulin independence in type I diabetes after transplantation of unpurified islets from single donor with 15-deoxyspergualin. L ancet 341: 19-21

6. International islet transplant registry (1995) Newsletter 1995; 5; N o 1: 14

7. Ricordi C, Lacy PE, Scharp DW (1989) A utomated islet isolation from human pancreas. Diabetes 38 [Suppl]: 140142

8. Socci C, D avalli A M, V ignali A et al. (1993) A significant increase of islet yield by early injection of collagenase into the pancreatic duct of young donors. Transplantation 55: 661-663

9. Warnock $G L, K$ neteman $N M, R$ yan $E A, R$ abinovitch $A$, R ajotte RV (1992) L ong-term follow-up after transplantation of insulin-producing pancreatic islets into patients with type 1 (insulin-dependent) diabetes mellitus. Diabetologia 35: 89-95

10. Comitti R, Racchetti G, G nocchi P, Morandi E, G alante Y M (1987) A monoclonal-based, two site enzyme immunoassay of human insulin. J I mmunol M ethods 99: 25-37

11. Scopsi L, A ndreola S, Socci C et al. (1994) Immunocytochemical detection and characterization of intrahepatic human pancreatic islets after combined liver-islet allotransplantation. Cell Transplantation 3: 499-508

12. D avalli A M , R icordi C, Socci C et al. (1991) A bnormal sensitivity to glucose of human islets cultured in a high clucose medium: partial reversibility after an additional culture in a normal glucose medium. J Clin E ndocrinol M etab 72: 202208

13. J uang J H , B onner-Weir S, Wu Y J, Weir G C (1994) B eneficial influence of glycemic control upon the growth and function of transplanted islets. D iabetes 43: 1334-1339

14. M irouze J, Selam J L, Pham TC, Mendoza E, Orsetti A (1978) Sustained insulin induced remission of juvenile diabetes by means of external artificial pancreas. Diabetologia 14: 223-227

15. Secchi A , D ubernard J M , La Rocca E et al. (1991) Endocrinometabolic effets of whole versus segmental pancreas allotransplantation in diabetic patients. A two-year followup. Transplantation 51: 625-629

16. Secchi A, M artinenghi S, Caldara R et al. (1991) First peak release after intravenous glucose and arginine is maintained for 3 years after segmental pancreas transplantation. D iabetologia 34 [Suppl 1]: 53-56 